\title{
INTEGRASI SENTRIFUGASI SUHU RENDAH DENGAN OPTIMASI EKSTRAKSI ENZIMATIS MINYAK MATA TUNA MENGGUNAKAN RE- SPONSE SURFACE METHODOLOGY
}

\author{
Wini Trilaksani*, Bambang Riyanto, Tati Nurhayati, Joko Santoso, Ikram Abi Hamzah Kurniawan \\ Diterima: 22 September 2021/Disetujui: 12 Desember 2021 \\ *Penulis korespondensi : wtrilaksani@apps.ipb.ac.id
}

Departemen Teknologi Hasil Perikanan, IPB University, Jalan Agatis, Kampus IPB Dramaga 16680 Bogor

Cara sitasi: Trilaksani W, Riyanto B, Nurhayati T, Santoso J, Kurniawan IAH. 2021. Integrasi sentrifugasi suhu rendah dengan optimasi ekstrasksi enzimatis minyak mata tuna menggunakan response . Jurnal Pengolahan Hasil Perikanan Indonesia. 24(3): 395-406.

\begin{abstract}
Abstrak
Mata tuna yang kaya akan asam lemak omega-3 eicosapentaenoic acid dan docosahexaenoic acid dapat diperoleh dengan ekstraksi suhu rendah tetapi rendemen yang diperoleh belum maksimal. Nilai rendemen minyak mata tuna dapat ditingkatkan dengan hidrolisis enzimatis. Response surface methodology (RSM) dapat membantu menganalisis pengaruh faktor-faktor terhadap respon untuk mengoptimalkan kondisi hidrolisis enzimatis. Tujuan penelitian ini adalah maksimalisasi rendemen minyak, menentukan kondisi optimum ekstraksi enzimatis minyak mata tuna dengan faktor konsentrasi papain dan waktu hidrolisis yang berbeda menggunakan pemodelan central composite design-face centered (CCDFC) pada RSM, dan determinasi karakteristik minyak hasil ekstraksi dengan suhu $55^{\circ} \mathrm{C}$ dan enzim papain 100.000 $\mathrm{U} / \mathrm{g}$. Kondisi hasil validasi optimum hidrolisis enzimatis minyak mata tuna menghasilkan nilai rendemen $11,24 \pm 0,09 \%$ pada konsentrasi 1,02\% enzim papain selama 3 jam. Kandungan EPA dan DHA minyak mata tuna pada kondisi optimum tergolong sangat tinggi yaitu 6,02\% EPA dan 30,30\% DHA dari 99,90\% total asam lemak yang teridentifikasi.
\end{abstract}

Kata kunci: asam lemak omega-3, hidrolisis enzimatis, mata tuna, response surface methodology, stunting

\section{Integration of Low Temperature Centrifugation with Optimization of Tuna Eye Oil Enzymatic Extraction Using Response Surface Methodology}

\begin{abstract}
Tuna eye oil which is rich in omega-3 fatty acids eicosapentaenoic acid and docosahexaenoic acid can be obtained by low temperature extraction however the yield was not optimum yet. The yield value of tuna eye oil can be increased with enzymatic hydrolysis. Response Surface Methodology (RSM) can help analyze the effect of factors on the response to optimize the conditions of enzymatic hydrolysis. The purpose of this study was to maximization of oil yield, determine the optimum conditions for enzymatic extraction of tuna eye oil with different papain enzyme concentration and hydrolysis time using central composite design-face centered (CCDFC) modeling on RSM and determination of oil extracted characteristics with a temperature $55^{\circ} \mathrm{C}$ and papain enzyme $100.000 \mathrm{U} / \mathrm{g}$. The validation optimum of the enzymatic hydrolysis resulted in a yield value of $11.24 \pm 0.09 \%$ at the concentration of $1.02 \%$ papain enzyme for 3 hours. The EPA and DHA content of tuna eye oil at the optimum condition was classified as very high, 6.02\% EPA and $30.30 \%$ DHA from $99.90 \%$ of the total identified fatty acids.
\end{abstract}

Keywords: enzymatic hydrolysis, omega-3 fatty acids, response surface methodology, stunting, tuna's eye 


\section{PENDAHULUAN}

Tuna merupakan komoditas ekspor unggulan Indonesia (KKP 2017). Tuna diekspor dalam bentuk loin dan kaleng yang menyisakan hasil samping mencapai 40\% dari bobot keseluruhan (Riyanto 2013). Renuka et al. (2016) melaporkan bahwa kepala tuna, khususnya mata tuna dapat diolah menjadi minyak ikan dan berpotensi sebagai sumber baru asam lemak omega-3 rantai panjang/long chain omega-3 fatty acid (LCn3FA) yang baik bagi kesehatan manusia, terutama eicosapentaenoic acid (20:5, n3; EPA) (7\%) dan docosahexaenoic acid (22:6, n-3; DHA) (35\%). Persentase tersebut cukup tinggi bila dibanding DHA pada sarden $(6,9 \pm 1,5 \%)$ yang merupakan ikan-ikan penghasil minyak (Mohanty et al. 2016).

Ekstraksi dan isolasi LCn-3FA telah banyak dilakukan menggunakan berbagai metode konvensional. Penggunaan bahan kimia dan suhu tinggi pada metode konvensional dapat menurunkan nilai atau konsentrasi LCn-3FA (Trilaksani et al. 2014). Ekstraksi dengan pelarut kimia (metode goldfisch (AOAC 1975), dan kloroform/ metanol (Bligh dan Dyer (1959); Folch et al. (1957)) merupakan ekstraksi yang sangat rumit, karena harus melalui tahap pemisahan pelarut yang membutuhkan energi besar dan menyebabkan kontaminan bagi lingkungan (Ramakrishnan et al. 2013). Ekstraksi suhu rendah misalnya pendinginan dan sentrifugasi serta enzimatis menjadi solusi dalam mengatasi hal tersebut untuk menghasilkan minyak ikan dengan kualitas yang baik dan lebih murni (Trilaksani et al. 2020).

Ekstraksi enzimatis minyak kepala salmon dengan protease tumbuhan (bromelin) telah dilakukan Mbatia et al. (2010) dengan rendemen yang dihasilkan mencapai $12,2 \pm 1,1 \%$ (b/b). Papain (EC 3.4.22.2) merupakan salah satu protease tumbuhan yang secara alami terdapat pada getah pepaya (Carica papaya). Papain tergolong jenis endopeptidase (endoproteinase) yang dapat memutus ikatan peptida pada tempattempat tertentu dalam molekul protein serta tidak memengaruhi gugus di ujung molekul (Damodaran dan Parkin 2017). Enzim papain dapat memecah kombinasi antara protein dan lemak pada kondisi $\mathrm{pH}$ optimum yang cenderung netral (6-8) dan stabil pada suhu pemanasan sedang $\left(40-60^{\circ} \mathrm{C}\right)$ dengan cara memotong protein kompleks menjadi asam amino sederhana sehingga membuat minyak yang terperangkap mudah untuk dipisahkan (Fernàndez-Lucas et al. 2017). Qi-Yuan et al. (2016) menyampaikan bahwa ekstraksi minyak dapat ditingkatkan melalui pra-hidrolisis menggunakan protease dan sentrifugasi serta difokuskan pada tahap optimasi proses. Tahap optimasi proses tersebut dapat dilakukan dengan beberapa cara, salah satunya dengan metode response surface methodology (RSM).

RSM merupakan metode statistik untuk pemodelan optimalisasi beberapa variabel yang menentukan kondisi proses optimal. RSM dapat diterapkan untuk optimasi dalam proses ekstraksi, salah satunya hidrolisis enzimatis produk hasil samping perikanan (Qi-Yuan et al. 2016). Beberapa model yang terdapat dalam RSM, di antaranya central composite design-face centered (CCDFC) yang memiliki tingkat akurasi prediksi cukup tinggi dan minimal hanya membutuhkan kombinasi dua faktor. Optimasi ekstraksi enzimatis minyak mata tuna kombinasi faktor konsentrasi papain dan waktu hidrolisis dengan RSM belum pernah dilakukan. Penelitian ini bertujuan menentukan kondisi optimum ekstraksi enzimatis minyak mata tuna dengan faktor konsentrasi papain dan waktu hidrolisis yang berbeda menggunakan permodelan CCDFC pada RSM, dan determinasi karakteristik minyak hasil ekstraksi dengan suhu $55^{\circ} \mathrm{C}$ dan enzim papain $100.000 \mathrm{U} / \mathrm{g}$.

\section{BAHAN DAN METODE Bahan dan Alat}

Bahan utama yang digunakan adalah mata tuna (Thunnus sp.) yang diambil pada 27 Desember 2019 di PT Ruangan Pendingin Indonesia, Muara Baru, Jakarta Utara. Bahan yang digunakan untuk hidrolisis minyak mata tuna adalah enzim papain (powder) (SGonek, warna putih, food grade, $100.000 \mathrm{U} / \mathrm{g}$ ). Bahan yang digunakan untuk analisis mutu minyak meliputi $\mathrm{CHCl}_{3}, \mathrm{CH}_{3} \mathrm{COOH}, \mathrm{Na}_{2} \mathrm{~S}_{2} \mathrm{O}_{3} 0,01 \mathrm{~N}$, $\mathrm{KI}, \mathrm{KOH} 0,1 \mathrm{~N}, p$-anisidin, pati $1 \%$, isooktan, indikator fenoiftalein (Merck, Jerman), dan 
alkohol 95\%. Bahan yang digunakan untuk analisis keragaan asam lemak meliputi Supelco TM37 component fatty acid methyl ester (FAME) mix, $\mathrm{NaOH} 0,5 \mathrm{~mL}, \mathrm{BF}_{3} 20 \%$, $\mathrm{NaCl}$ jenuh. Peralatan yang digunakan dalam penelitian ini antara lain alat sentrifugasi (HIMAC CR no. R12A6904357D0 Hitachi, Jepang) timbangan analitik (Joil), alat pembeku (Frigigate F-200), penangas air kocok (WiseBath ${ }^{\oplus}$ WSB Series, Swiss), kromatografi gas 2010 plus, dan spektrofotometer UV-Vis 2500 (Shimadzu, China).

\section{Metode Penelitian \\ Preparasi dan karakterisasi mata tuna (Murado et al. 2012)}

Mata tuna dipotong sebanyak dua sampai tiga bagian. Pemisahan dilakukan dengan cara membuang bagian keras, lensa dan sklera. Daging dihaluskan untuk ekstraksi minyak ikan. Karakterisasi mata tuna meliputi kadar air, abu, lemak, protein, dan karbohidrat (AOAC 2005), pengukuran morfometrik, dan organoleptik dengan spesifikasi kenampakan mata sesuai dengan SNI 2729:2013 tentang ikan segar dan SNI 2346:2015 tentang ketentuan panelis.

\section{Rancangan ekstraksi minyak mata tuna (modifikasi Mbatia et al. 2010 dan Trilaksani et al. 2020)}

Ekstraksi minyak mata tuna meliputi (1) ekstraksi suhu rendah (sentrifugasi) tanpa enzimatis, (2) ekstraksi suhu rendah (sentrifugasi) dengan enzimatis, dan (3) ekstraksi suhu rendah (sentrifugasi), enzimatis, dan suhu rendah (sentrifugasi) kembali. Konsentrasi enzim 0,5\% dan waktu hidrolisis enzimatis selama satu jam. Ekstraksi terbaik ditentukan berdasarkan nilai rendemen tertinggi.

Ekstraksi suhu rendah tanpa enzimatis dilakukan dengan sentrifugasi $(11.200 \mathrm{~g}, 4$ ${ }^{\circ} \mathrm{C}, 30$ menit). Ekstraksi suhu rendah dengan enzimatis dilakukan dengan penambahan papain dengan konsentrasi $0,5 \%$ lalu diinkubasi pada penangas air kocok selama satu jam, $150 \mathrm{rpm}$ (hidrolisis) kemudian disentrifugasi (11.200 g, $4{ }^{\circ} \mathrm{C}, 30$ menit). Ekstraksi suhu rendah, enzimatis, dan suhu rendah kembali dilakukan sentrifugasi (11.200 g, $4{ }^{\circ} \mathrm{C}, 30$ menit) dan dilakukan pemisahan dengan komponen lainnya (substrat). Substrat kemudian ditambahkan papain 0,5\% lalu diinkubasi pada penangas air kocok selama satu jam, $150 \mathrm{rpm}$ (hidrolisis) kemudian disentrifugasi kembali $\left(11.200 \mathrm{~g}, 4{ }^{\circ} \mathrm{C}, 30\right.$ menit).

\section{Optimasi ekstraksi enzimatis minyak mata tuna dengan metode RPM (modifikasi Mbatia et al. (2010) dan Ramakrishnan et al. (2013))}

Nilai optimum rendemen minyak mata tuna ditentukan dari dua faktor yaitu konsentrasi papain (\%) dan waktu hidrolisis (jam). Konsentrasi papain ditetapkan pada rentang $0,5-1,5 \%$ (titik pusat $1 \%$ ) dan waktu hidrolisis ditetapkan pada rentang 1-3 jam (titik pusat dua jam). Konsentrasi papain mengacu Ramakrishnan et al. (2013) bahwa menaikkan konsentrasi enzim hingga $1 \%$ dapat mencapai hasil maksimum untuk ekstraksi minyak ikan. Waktu hidrolisis mengacu Mbatia et al. (2010) bahwa nilai maksimum minyak ikan dihasilkan dengan waktu hidrolisis selama dua jam.

Substrat terdiri dari light lipid, hidrolisat protein cair, dan endapan dilakukan penimbangan kemudian ditambahkan papain dengan konsentrasi yang disarankan oleh perangkat lunak Design Expert 11.0, yaitu 0,5\%-1,5\% serta lama waktu reaksi yang disarankan adalah 1-3 jam lalu diinkubasi pada penangas air kocok dengan kecepatan 150 rpm pada suhu $55^{\circ}$ setelah itu disentrifugasi $\left(11.200 \mathrm{~g}, 4{ }^{\circ} \mathrm{C}, 30\right.$ menit). Minyak mata tuna dianalisis yang meliputi rendemen minyak (AOAC 1995) keragaan asam lemak (AOAC 2000), nilai anisidin (AOCS 1998), nilai peroksida (AOAC 2005), nilai total oksidasi (AOAC 2005), nilai asam (AOCS 1998) dan asam lemak bebas (AOAC 2005).

\section{Analisis Data}

Rancangan percobaan yang digunakan adalah CCDFC dari RSM menggunakan dua variabel bebas konsentrasi enzim papain $\left(\mathrm{X}_{1}\right)$ dan waktu hidrolisis $\left(\mathrm{X}_{2}\right)$ sedangkan variabel respons adalah nilai rendemen minyak mata tuna. Desain rancangan percobaan pada Table 1 dan 2 diperoleh dengan bantuan perangkat 
lunak Design Expert versi 11. CCDFC terdiri dari tiga bagian:

1. Titik sudut (corner points $)=n f$ dengan $x i=$ $-1,1 ; \mathrm{i}=1, \ldots, \mathrm{k}$ membentuk bagian faktorial pada desain.

2. Titik pusat (centre points $)=\mathrm{nc}$ dengan $x i=$ $0 ; i=1, \ldots, \mathrm{k}$

3. Titik aksial (axial points $)=\alpha$ dengan $x i=$ $-\alpha, \alpha ; i=1, \ldots, k$. Nilai ini ditentukan oleh jumlah variabel faktor.

Titik aksial $(\alpha)$ penelitian ini menggunakan dua variabel faktor sehingga nilai aksialnya $(\alpha)=\left(2^{2}\right)^{1 / 4}=1$.

Table 1 Correlation of variables and factor codes on RSM

\begin{tabular}{lccc}
\hline \multirow{2}{*}{ Factor variable } & \multicolumn{3}{c}{ Factor code } \\
\cline { 2 - 4 } & -1 & 0 & 1 \\
\hline Papain concentration $(\mathrm{X} 1)(\%)$ & 0.5 & 1 & 1.5 \\
Hydrolysis time $\left(\mathrm{X}_{2}\right)(\mathrm{h})$ & 1 & 2 & 3 \\
\hline
\end{tabular}

Data hasil eksperimen di laboratorium dioptimasi untuk mengetahui pengaruh linier, kuadrat, dan interaksi dari variabel bebas selama ekstraksi yang dinyatakan dalam persamaan orde ke-1 linier dan orde ke-2 kuadrat:
Desain model orde 1

Desain model orde 2

$$
\mathrm{Y}=\beta_{0}+=\sum_{1}^{n}
$$

$$
\mathrm{Y}=\beta_{0}+\sum_{i=1}^{k} \beta_{\mathrm{i}} \mathrm{X}_{\mathrm{i}}+\sum_{i=1}^{k} \beta_{\mathrm{ii}} \mathrm{X}^{2}+\sum \sum_{i<j} \beta_{\mathrm{j} j} \mathrm{X}_{\mathrm{i}} \mathrm{X}_{\mathrm{j}}+\varepsilon
$$

Keterangan:

$\mathrm{Y}=$ Hasil perkiraan respons yang diinginkan (tingkat rendemen)

$\mathrm{X}_{\mathrm{i}}=$ Peubah yang meliputi konsentrasi enzim papain dan waktu hidrolisis

$\beta_{0}=$ Koefisien model

$\beta_{\mathrm{i}}=$ Pengaruh linier peubah terhadap respons

$\beta_{\mathrm{ij}}=$ Pengaruh interaksi antar peubah terhadap respons

$\beta_{\mathrm{ii}}=$ Pengaruh kuadratik peubah terhadap respons

$\varepsilon_{\mathrm{ij}}=$ Gangguan error

\section{HASIL DAN PEMBAHASAN \\ Karakteristik Mata Tuna}

Mata tuna yang digunakan memiliki diameter rata-rata $5,98 \pm 0,35 \mathrm{~cm}$ dan bobot utuh rata-rata $90,63 \pm 5,02$ g. Proporsi mata tuna memiliki empat bagian, mata tuna bagian lunak mengandung $90 \%$ proporsi bagian yang terdiri dari daging $27,10 \pm 2,71$ $\mathrm{g}$ dan humor bening (vitreous humor)

Table 2 Design experimental of central composite design-face centered on RSM

\begin{tabular}{crrrrr}
\hline & \multicolumn{2}{c}{ Factor code } & \multicolumn{2}{c}{ Factor actual } & \\
\cline { 2 - 4 } & $\mathrm{X}_{1}$ & $\mathrm{X}_{2}$ & $\begin{array}{c}\text { Papain } \\
\text { concentration }(\%)\end{array}$ & $\begin{array}{c}\text { Hydrolysis } \\
\text { time }(\mathrm{h})\end{array}$ & Response \\
\hline 1 & -1 & 1 & 0.5 & 3 & $\mathrm{Y} 1$ \\
2 & 0 & 0 & 1 & 2 & $\mathrm{Y} 2$ \\
3 & -1 & 0 & 1.5 & 2 & $\mathrm{Y} 3$ \\
4 & -1 & 0 & 0.5 & 2 & $\mathrm{Y} 4$ \\
5 & 1 & 1 & 1.5 & 3 & $\mathrm{Y} 5$ \\
6 & 1 & -1 & 1.5 & 1 & $\mathrm{Y} 6$ \\
7 & 0 & -1 & 1 & 1 & $\mathrm{Y} 7$ \\
8 & 0 & 0 & 1 & 2 & $\mathrm{Y} 8$ \\
9 & 0 & 1 & 1 & 3 & $\mathrm{Y} 9$ \\
10 & -1 & -1 & 0.5 & 1 & $\mathrm{Y} 10$ \\
11 & 0 & 0 & 1 & 2 & $\mathrm{Y} 11$ \\
12 & 0 & 0 & 1 & 2 & $\mathrm{Y} 12$ \\
13 & 0 & 0 & 1 & 2 & $\mathrm{Y} 13$ \\
\hline Note: X1 = Papain concentration (\%); $2=$ Hydrolysis time (h) & &
\end{tabular}


$54,29 \pm 1,95 \mathrm{~g}$, sementara mata tuna bagian keras mengandung $10 \%$ proporsi bagian

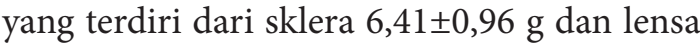

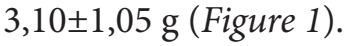

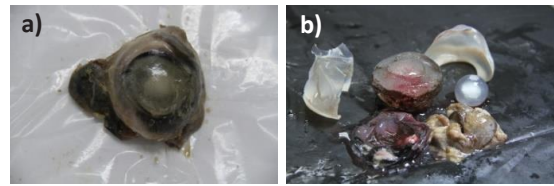

Figure 1 Visual of tuna eye; a) tuna's eye and b) tuna's eye proportion

Analisis organoleptik kesegaran mata tuna dengan spesifikasi kenampakan mata sesuai SNI 2729:2013 memperlihatkan mata tuna masih memiliki kenampakan bola mata agak cekung, kornea agak keruh, pupil agak keabu-abuan, dan agak mengilap spesifik jenis ikan dengan nilai 6,24. Komposisi kimia mata tuna terdiri dari kadar air

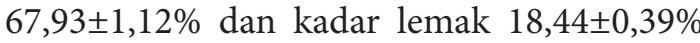
yang merupakan komponen tertinggi. Kadar

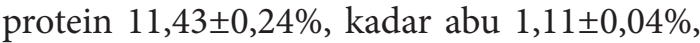
dan karbohidrat (by difference) 1,09 $\pm 0,58 \%$. Rendemen minyak mata tuna tertinggi $(15,03 \pm 2,43 \%)$ dihasilkan dari perlakuan ekstraksi suhu rendah (sentrifugasi), enzimatis, dan suhu rendah (sentrifugasi) kembali (Table 3). Tingginya rendemen minyak mata tuna tersebut disebabkan adanya akumulasi minyak hasil sentrifugasi suhu rendah dengan minyak hasil kombinasi ekstraksi enzimatis dengan sentrifugasi suhu rendah. Minyak hasil sentrifugasi pertama menyisakan daging mata tuna dengan ukuran yang lebih kecil karena pemisahan sebagian minyak dengan substratnya. Substrat tersebut diduga masih mengandung minyak yang terikat dengan protein kompleks sehingga dilakukan ekstraksi enzimatis dan sentrifugasi kembali untuk mendapatkan rendemen minyak yang maksimal, semakin kecil ukuran bahan akan semakin besar luas permukaannya sehingga minyak dapat dengan mudah dilepaskan. Luas permukaan bahan yang besar juga diduga dapat membuat penetrasi enzim lebih cepat saat proses hidrolisis. Hidrolisis enzimatis dengan protease dapat memutus ikatan peptida proteolitik yang memfasilitasi degradasi protein pada jaringan mata tuna dan pelepasan minyak (Carvajal dan Mozuraityte 2016).

\section{Optimasi Ekstraksi Enzimatis Minyak Mata Tuna menggunakan RSM}

Nilai respons rendemen minyak mata tuna ekstraksi enzimatis dengan rancangan CCDFC dalam RSM disajikan pada Table 4. Model yang direkomendasikan adalah kuadratik dari respons rendemen minyak mata tuna ekstraksi enzimatis. Pada perangkat lunak tersebut digunakan tingkat signifikansi $5 \%(0,05)$ sehingga penentuan model terbaik berdasarkan parameter tingkat signifikansi harus di bawah 0,05 ( $\mathrm{p}<0,05)$ sementara uji Lack of Fit harus tidak signifikan $(\mathrm{p}>0,05)$ untuk menunjukkan bahwa model yang digunakan telah sesuai. Analisis ragam menunjukkan p-value Lack of Fit 0,7413 lebih besar dari tingkat signifikansi 0,05 yang telah ditentukan, sehingga dapat dinyatakan model telah sesuai untuk respons yang digunakan. Nilai $\mathrm{R}^{2}$ diperoleh 0,9350 sehingga diduga seluruh faktor yang diamati memiliki pengaruh nyata pada respons.

Nilai adjusted $\mathrm{R}^{2}$ dan predicted $\mathrm{R}^{2}$ yang baik adalah keduanya lebih dari 0,70. Selisih nilai adjusted $\mathrm{R}^{2}$ dan predicted $\mathrm{R}^{2}$ sangat berpengaruh terhadap kesesuaian model, yaitu tidak lebih dari 0,2. Nilai adjusted $\mathrm{R}^{2}$ yang diperoleh dari perangkat lunak 0,8886, sementara nilai prediction $\mathrm{R}^{2} \quad 0,7763$. Selisih

Table 3 Extraction of tuna's eye oil

\begin{tabular}{lrrr}
\hline \multicolumn{1}{c}{ Research design } & $\begin{array}{c}\text { Papain } \\
\text { concentration } \\
(\%)\end{array}$ & $\begin{array}{c}\text { Hydrolysis } \\
\text { time (h) }\end{array}$ & Yield \\
\hline Low temperature extraction without enzymatic & 0 & 0 & $5.58 \pm 0.01$ \\
Low temperature extraction with enzymatic & 0.5 & 1 & $12.86 \pm 2.02$ \\
Low temperature extraction, enzymatic, and & 0.5 & 1 & $15.03 \pm 2.43$ \\
low temperature again & & & \\
\hline
\end{tabular}


Table 4 Response value of enzymatic extraction tuna eye oil with CCDFC design in RSM

\begin{tabular}{crrrrrr}
\hline & \multicolumn{2}{c}{ Coded variable } & \multicolumn{2}{c}{ Original variable } & \multicolumn{2}{c}{ Yield (\%) } \\
\cline { 2 - 7 } & $\mathrm{X}_{1}$ & $\mathrm{X}_{2}$ & $\begin{array}{c}\text { Papain } \\
\text { concentration }(\%)\end{array}$ & $\begin{array}{c}\text { Hydrolysis } \\
\text { time (h) }\end{array}$ & Actual & Prediction \\
\hline 1 & 0 & 0 & 1 & 2 & $8.45 \pm 0.86$ & 8.24 \\
2 & -1 & 0 & 0.5 & 2 & $6.87 \pm 0.07$ & 6.75 \\
3 & 0 & -1 & 1 & 1 & $10.21 \pm 0.61$ & 10.42 \\
4 & -1 & -1 & 0.5 & 1 & $9.24 \pm 0.15$ & 9.14 \\
5 & 0 & 0 & 1 & 2 & $8.13 \pm 0.43$ & 8.24 \\
6 & 1 & 0 & 1.5 & 2 & $6.72 \pm 0.25$ & 6.62 \\
7 & 0 & 0 & 1 & 2 & $8.99 \pm 0.24$ & 8.24 \\
8 & 0 & 0 & 1 & 2 & $7.67 \pm 0.08$ & 8.24 \\
9 & 0 & 0 & 1 & 2 & $7.72 \pm 0.09$ & 8.24 \\
10 & -1 & 1 & 0.5 & 3 & $9.54 \pm 0.19$ & 9.76 \\
11 & 1 & -1 & 1.5 & 1 & $8.71 \pm 1.14$ & 8.60 \\
12 & 0 & 1 & 1 & 3 & $11.9 \pm 0.06$ & 11.46 \\
13 & 1 & 1 & 1.5 & 3 & $9.84 \pm 0.53$ & 10.05 \\
\hline Note: X1 = Papain concentration (\%); X2 = Hydrolysis time (h) & & & &
\end{tabular}

nilai tersebut adalah $0,1123(<0,2)$ dan kedua nilai juga sudah melebihi batas minimal yang baik $(>0,70)$, sehingga menunjukkan data model yang digunakan sangat baik. Persamaan linier yang mengoptimalkan respons rendemen minyak mata tuna sebagai berikut:

Oil yield $(\%)=+8.24-0.0633^{*}$ Conc. of enzyme $+0.5200 *$ Time of hydrolysis $+0.2075{ }^{\star}$ Conc. Of enzyme * Time of hydrolysis $-1.55{ }^{*}$ Conc. of enzyme $e^{2}+2.71 *$ Time of hydrolysis ${ }^{2}$

Persamaan model tersebut menunjukkan bahwa respons nilai rendemen minyak mata tuna ekstraksi enzimatis dipengaruhi oleh semua faktor yang diamati. Setiap faktor memengaruhi respons sesuai dengan nilai konstanta yang ada. Konstanta positif memberi nilai setara dengan respons dan konstanta negatif memberi pengaruh berbalikan dengan respons.

\section{Analisis Kombinasi Faktor Konsentrasi Papain dan Waktu Hidrolisis pada Respons Rendemen Minyak Mata Tuna}

Faktor konsentrasi papain dan waktu hidrolisis memengaruhi hidrolisis enzimatik minyak mata tuna yang dilakukan. Grafik tiga dimensi dan kontur (Figure 2) menunjukkan hubungan antara faktor $\mathrm{X}_{1}$ dan $\mathrm{X}_{2}$ yang menampilkan kondisi kedua faktor memiliki nilai respons maksimal pada wilayah yang ditandai dengan warna merah. Persentase tertinggi dari hasil minyak ikan yang diperoleh adalah $11,9 \pm 0,06 \%$ pada run $12(1 \%$ konsentrasi enzim selama 3 jam), sementara untuk persentase terendah dari hasil minyak ikan adalah $6,72 \pm 0,25 \%$ pada run $6(1,5 \%$ konsentrasi papain selama 2 jam).

Ramakrishnan et al. (2013) melaporkan bahwa ekstraksi minyak ikan makerel menggunakan enzim alkalase selama 1-4 jam, peningkatan konsentrasi enzim dari 0,5$2 \%$ dapat meningkatkan rendemen minyak. Liu et al. (2020) juga melaporkan bahwa ekstraksi minyak salmon dengan menaikkan level konsentrasi enzim dari $0,1 \%$ menjadi $1 \%$ hanya berpengaruh sedikit terhadap rata-rata rendemen minyak. Peningkatan konsentrasi enzim tidak selalu mengarah pada peningkatan hasil minyak yang diperoleh. Mbatia et al. (2010) menyatakan bahwa penambahan konsentrasi enzim dapat meningkatkan laju hidrolisis, tetapi tidak secara signifikan meningkatkan hasil minyak. Peningkatan sebanyak tiga kali lipat dari 0,5\% konsentrasi 

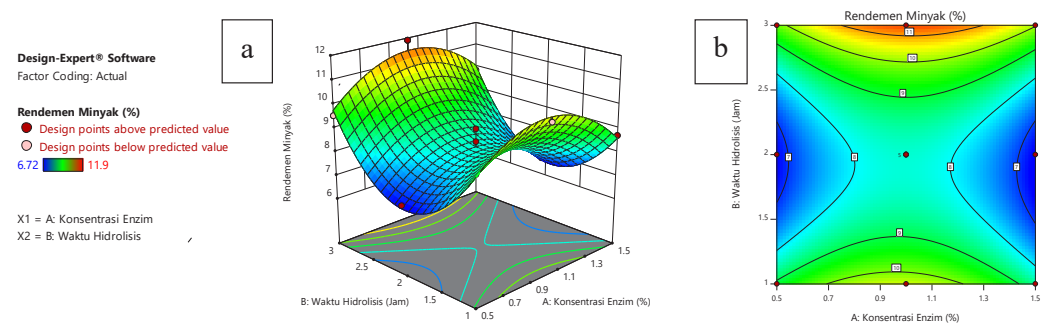

Figure 2 Graphic of the effect of papain concentration and hydrolysis time on the response to tuna eye oil yield; a) Three-dimensional graph and b) Contour graph

enzim hanya berkontribusi sedikit terhadap peningkatan hasil minyak, oleh sebab itu 0,5 $1 \%(\mathrm{~b} / \mathrm{b})$ konsentrasi enzim dianggap sebagai titik optimal, selain itu konsentrasi enzim yang rendah dapat mengurangi biaya yang terkait dengan enzim pada skala produksi (Iberahim et al. 2020).

Mbatia et al (2010) melakukan ekstraksi minyak kepala salmon selama 14 jam dengan konsentrasi bromelin 0,5\% menghasilkan $12,2 \%$ minyak ikan (pada jam ke-2) dari total kandungan lipid $17,6 \pm 1,5 \%$. Lama waktu hidrolisis yang diperpanjang dari 4-14 jam tidak akan meningkatkan hasil minyak tetapi akan menghasilkan perubahan warna menjadi cokelat. Penurunan hasil minyak setelah 2-3 jam disebabkan interaksi lebih banyak lipid dengan protein terhidrolisis seperti saat penambahan jumlah air yang tinggi ke dalam reaksi. Iberahim et al. (2018) melaporkan bahwa lama waktu hidrolisis yang ditingkatkan dari 60 menit menjadi 180 menit menghasilkan peningkatan hasil minyak ikan lele (Clarias gariepinus) dari $14,49 \pm 0,50 \%$ menjadi $15,91 \pm 0,20 \%$, hal tersebut membuktikan bahwa ketika lama waktu hidrolisis ditingkatkan maka laju hidrolisis akan meningkat juga karena enzim mampu bereaksi lebih terhadap substrat untuk menghasilkan minyak. Hidrolisis enzimatis dengan waktu antara 1-4 jam sudah cukup untuk melepaskan lipid (Ramakrishnan et al. 2013).

\section{Optimasi Respons dan Validasi Kondisi Optimum}

Optimasi respons dilakukan untuk mendapatkan kombinasi model terbaik sehingga diperoleh hasil rendemen minyak mata tuna sesuai yang diinginkan dengan menggabungkan variabel respons dan variabel bebas. Penentuan optimasi respons dilakukan dengan memaksimalkan respons. Plot overlay (Figure 3) dari perangkat lunak dengan memprediksi wilayah optimal untuk mendapatkan nilai maksimum respons serta variabel yang diinginkan.

Solusi optimasi variabel respons pada ekstraksi enzimatis minyak mata tuna mendapatkan hasil pada konsentrasi enzim $1,02 \%$ dan waktu hidrolisis 3 jam berdasarkan perangkat lunak dengan hasil respons adalah $11,47 \%$. Nilai optimasi hasil pengolahan ditunjukkan dengan nilai desirability yang mendekati 1. Solusi terbaik pada model memiliki nilai desirability sebesar 0,916 dengan persentase kemungkinan $91,6 \%$. Solusi tersebut menggunakan faktor konsentrasi papain sebesar $1,02 \%$ dengan waktu hidrolisis selama 3 jam. Perlakuan pada

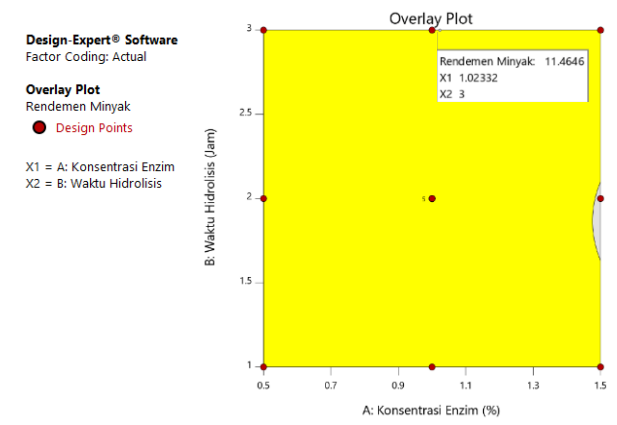

Figure 3 Overlay plot graph of enzymatic extraction tuna eye oil yield 
titik optimal yang ditunjukkan perangkat lunak diprediksikan rendemen minyak mata tuna sebesar $11,47 \%$. Nilai optimasi tersebut perlu dilakukan validasi pada penerapannya.

Validasi terhadap prediksi variabel respons dilakukan setelah mendapatkan hasil optimasi respons. Nilai respons aktual pada tahapan ini dibandingkan dengan nilai respon prediksi yang diberikan oleh perangkat lunak. Nilai aktual didapat dari hasil pengamatan laboratorium sedangkan nilai prediksi didapat dari hasil pengolahan data dengan pernagkat lunak Design Expert 11. Hasil uji validasi terhadap variabel respons pada kondisi optimum faktor konsentrasi papain $1 \%$ dan waktu hidrolisis 3 jam sebesar 11,24 $\pm 0,09 \%$. Nilai tersebut mendekati nilai prediksi $(11,47 \%)$ dengan ketepatan pada respons yang diuji sebesar $98,08 \%$.

\section{Karakteristik Minyak Mata Tuna Ekstraksi Suhu Rendah dan Enzimatis Hasil Optimasi}

Ekstraksi minyak mata tuna menggunakan metode sentrifugasi suhu rendah dan enzimatis hasil optimasi memisahkan minyak dengan komponen daging dan fase cair lainnya menjadi empat lapisan. Lapisan tersebut terdiri dari minyak mata tuna, emulsi lipid-protein, cairan dan darah, serta endapan lipid-protein berbobot molekul besar (Figure 4). Mbatia et al. (2010) melaporkan bahwa hasil ekstraksi minyak dari kepala salmon dengan sentrifugasi kecepatan $2.000 \mathrm{~g}$ selama 15 menit pada suhu ruang $\left(25^{\circ} \mathrm{C}\right)$ menghasilkan empat lapisan, yaitu lapisan paling atas adalah minyak diikuti lapisan lipid-protein (emulsion), lapisan berair (aqueous), dan endapan sisa (sludge). Ramakrishnan et al. (2013) melakukan ekstraksi minyak ikan makarel menggunakan $0,5-2 \%(\mathrm{~b} / \mathrm{b})$ enzim alkalase pada suhu $55^{\circ} \mathrm{C}$ selama 1-4 jam menghasilkan empat lapisan, yaitu lapisan minyak, light lipid-protein, hidrolisat protein ikan cair, dan heavy lipidprotein serta endapan sisa (sludge). Lapisan tersebut dapat terpisah karena perbedaan bobot jenis setiap komponen sehingga minyak yang memiliki bobot jenis paling rendah akan terpisah ke bagian atas. Rendemen minyak mata tuna hasil sentrifugasi suhu rendah tertinggi adalah $10,33 \%$.

Analisis logam berat minyak mata tuna ekstraksi suhu rendah dan enzimatis hasil optimasi terdeteksi arsen (As) berturutturut adalah $3,61 \pm 0,02 \mathrm{mg} / \mathrm{kg}$ dan 3,92 $\pm 0,01$ $\mathrm{mg} / \mathrm{kg}$ serta tidak terdapatnya unsur logam berat lain yaitu merkuri $(\mathrm{Hg})$, timbel $(\mathrm{Pb})$, kadmium (Cd), dan timah (Sn). Nilai arsen yang terdeteksi lebih tinggi dari standar yang ditetapkan CODEX STAN 193-1995 Standard for Contaminants and Toxins in Food and Feed yaitu $0,1 \mathrm{mg} / \mathrm{kg}$.

Kandungan asam lemak bebas dan nilai asam pada minyak mata tuna ekstraksi suhu rendah $(0,57 \pm 0,01 \%$ dan $1,12 \pm 0,06$ $\mathrm{mg} \mathrm{KOH} / \mathrm{g}$ ) dan enzimatis hasil optimasi $(0,89 \pm 0,01 \%$ dan $1,76 \pm 0,03 \mathrm{mg} \mathrm{KOH} / \mathrm{g})$. Rendahnya nilai asam pada minyak mata tuna tersebut menunjukkan bahwa terdapat sedikit kerusakan yang terjadi saat proses pengolahan atau penyimpanan (Mahesar et al. 2014). Nilai peroksida minyak mata tuna ekstraksi suhu rendah $(121,43 \pm 0,62 \mathrm{meq} / \mathrm{kg})$ dan enzimatis hasil optimasi $(205,95 \pm 0,55 \mathrm{meq} /$ $\mathrm{kg}$ ) tergolong sangat tinggi. Nilai tersebut
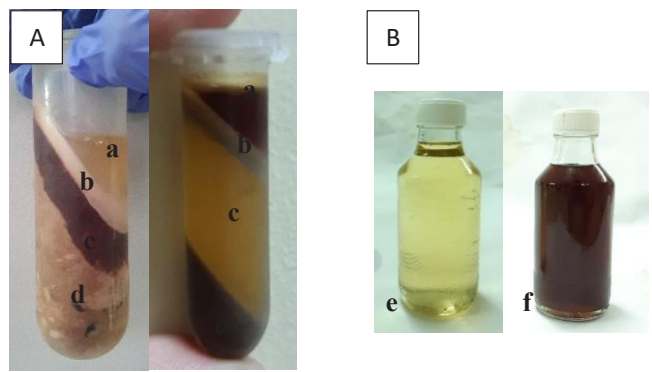

Figure 4 Visualization of extraction and centrifugation forms (A) separation of tuna's eye content (B) tuna's eye oil. (a) tuna's eye oil, (b) emulsion of lipid-protein, (c1) aqueous phase, (c2) aqueous protein hydrolysate, (d) sludge, (e) low temperature 
berada di atas batas aman mutu minyak yang ditetapkan oleh Codex (2017) yaitu $\leq 5 \mathrm{meq} /$ $\mathrm{kg}$. Tingginya nilai oksidasi minyak tersebut disebabkan oleh tingginya kandungan PUFA terutama EPA dan DHA yang sangat rentan teroksidasi (Kaushik et al. 2015). Nilai organoleptik mata tuna yang diperoleh adalah 6,24 (skala 1 sampai 9) yang menunjukkan sudah terjadinya kemunduran mutu, salah satunya adalah perubahan warna mata menjadi abu-abu kemerahan. Rustad (2010) menyampaikan bahwa percepatan oksidasi minyak sangat dipengaruhi oleh beberapa faktor, di antaranya paparan oksigen, cahaya, panas, dan tingkat ketidakjenuhan asam lemak. Nilai $p$-anisidin pada minyak mata tuna ekstraksi suhu rendah $(54,52 \pm 1,02 \mathrm{meq} /$ $\mathrm{kg})$ dan enzimatis hasil optimasi $(104,55 \pm 1,41$ $\mathrm{meq} / \mathrm{kg}$ ) diduga minyak tersebut mengalami masa penyimpanan yang cukup lama yaitu satu bulan sebelum dilakukan pengujian, selama masa penyimpanan minyak telah terjadi oksidasi tahap dua (sekunder) yang ditandai dengan dekomposisi senyawa hidroperoksida (produk oksidasi primer). Tingginya nilai peroksida dan nilai $p$-anisidin pada kedua sampel minyak mata tuna sangat memengaruhi nilai TOTOX minyak mata tuna ekstraksi suhu rendah $(297,39 \pm 0,22 \mathrm{meq} /$ $\mathrm{kg})$ dan enzimatis hasil optimasi $(516,45 \pm 0,31$ $\mathrm{meq} / \mathrm{kg}$ ) yang dihasilkan sebagai penentu adanya senyawa hidroperoksida, aldehida, dan keton dari degradasi asam lemak tak jenuh ganda (PUFA) dalam kondisi teroksidasi oleh suhu tinggi, paparan oksigen dan cahaya, serta kandungan senyawa logam. Karakteristik mutu minyak mata tuna ekstraksi suhu rendah dan enzimatis hasil optimasi dapat dilihat pada Table 5.
Kandungan asam lemak minyak mata tuna ekstraksi suhu rendah didominasi oleh PUFA. Kandungan asam lemak tertinggi adalah DHA mencapai 30,30\% diikuti oleh asam palmitat (SFA) $21,25 \%$, dan asam oleat (MUFA) 16,52\% serta EPA (PUFA) 6,12\%. Renuka et al. (2016) melaporkan bahwa kandungan asam lemak pada mata tuna sirip kuning didominasi oleh PUFA dengan DHA $36,72 \pm 1,11 \%$ dan EPA 7,07 $\pm 0,09 \%$.

Kandungan DHA minyak mata tuna ekstraksi suhu rendah (30,17\%) dan enzimatis hasil optimasi $(30,30 \%)$ memiliki nilai tertinggi dibandingkan sumber DHA lainnya, yaitu minyak ikan sarden dengan PUFA $30,00 \pm 0,27 \%$ dan DHA $16,85 \pm 0,90 \%$ (Renuka et al. 2016). Tingginya PUFA terutama DHA pada minyak mata tuna diduga karena DHA banyak ditemukan pada retina yang berperan sebagai pelindung dalam proses penangkapan cahaya. VanLeeuwen et al. (2018) melaporkan asam lemak DHA mencapai konsentrasi tertingginya di membran fotoreseptor (wilayah orbital mata) sebagai faktor pelindung saraf terhadap stres oksidatif dan berperan penting dalam perkembangan retina.

\section{Total Rendemen Minyak Mata Tuna Kombinasi Ekstraksi Suhu Rendah dan Hidrolisis Enzimatis terhadap Kandungan Lemak Mata Tuna}

Rendemen total minyak mata tuna yang diperoleh dari hasil kombinasi ekstraksi suhu rendah (sentrifugasi) dan hidrolisis enzimatis (1\% papain; 3 jam waktu hidrolisis) adalah $16,95 \%$, sedangkan kandungan lemak mata tuna adalah $18,44 \pm 0,39 \%$ dengan nilai oil recovery mencapai $91,91 \%$. Rendemen total

Table 5 Quality characteristics of tuna's eye oil

\begin{tabular}{lrrr} 
& \multicolumn{2}{c}{ Tuna's eye oil } & \\
\cline { 2 - 3 } \multicolumn{1}{c}{ Parameter } & $\begin{array}{c}\text { Low temperature } \\
\text { extraction }\end{array}$ & $\begin{array}{c}\text { Optimized } \\
\text { enzymatic extraction }\end{array}$ & Standard $^{*}$ \\
\hline Free fatty acid (\%) & $0.57 \pm 0.01$ & $0.89 \pm 0.01$ & - \\
Acid value $(\mathrm{mgKOH} / \mathrm{g})$ & $1.12 \pm 0.01$ & $1.76 \pm 0.03$ & $\leq 3$ \\
Peroxide value $(\mathrm{meq} / \mathrm{kg})$ & $121.43 \pm 0.62$ & $205.95 \pm 0.55$ & $\leq 5$ \\
P-anisidine value (meq/kg) & $54.52 \pm 1.02$ & $104.55 \pm 1.41$ & $\leq 20$ \\
Total oxidation $(\mathrm{meq} / \mathrm{kg})$ & $297.39 \pm 0.22$ & $516.45 \pm 0.31$ & $\leq 26$ \\
\hline${ }^{*}$ Codex Alimentarius Commission (CAC) $329-2017$ Standard for Fish Oil & &
\end{tabular}


minyak mata tuna $(16,95 \%)$ lebih rendah dari kandungan lemak mata tuna $(18,44 \pm 0,39 \%)$. Perbedaan hasil yang didapat diduga karena minyak pada mata tuna tidak terhidrolisis sempurna sehingga masih terperangkap di dalam lapisan emulsi dan lapisan heavy lipidprotein. Lapisan emulsiterbentuk dari interaksi antara lipid dan asam amino hidrofobik yang terletak di antara lapisan minyak dan cairan sehingga sebagian minyak terperangkap dan sulit dipisahkan dalam lapisan emulsi yang dapat memengaruhi perolehan nilai rendemen minyak (Liu et al. 2020).

\section{SIMPULAN DAN SARAN}

Kondisi optimum ekstraksi enzimatis minyak mata tuna menggunakan permodelan CCDFC pada RSM perangkat lunak Design Expert 11 dihasilkan kombinasi variabel konsentrasi enzim $1,023 \%$ dan waktu hidrolisis selama 3 jam. Kombinasi variabel tersebut menghasilkan rendemen minyak $11,24 \pm 0,09 \%$. Karakteristik minyak mata tuna hasil ekstraksi enzimatis memiliki parameter nilai peroksida, $p$-anisidin, dan total oksidasi yang tidakbelum sesuai dengan standar Codex. Penambahan variabel $\mathrm{pH}$ perlu ditambahkan memaksimalkan kerja enzim. Penanganan rantai dingin secara terintegrasi dari hulu dan pemurnian minyak ikan masih diperlukan untuk meningkatkan kualitas fisiko-kimia minyak mata tuna yang dihasilkan.

\section{DAFTAR PUSTAKA}

[AOAC] Association of Official Analytical Chemist. 1975. Official Methods of Analysis of the Association of Agricultural Chemists, $12^{\text {th }}$ edition. Washington (US): AOAC Int.

[AOAC] Association of Official Analytical Chemist. 1995. Official Methods of Analysis of the Association of Analytical Chemist. Washington (US): AOAC Int.

[AOAC] Association of Official Analytical Chemist. 2000. Official Methods of Analysis of the Association of Agricultural Chemists, $17^{\text {th }}$ edition. Washington (US): AOAC Int.

[AOAC] Association of Official Analytical Chemist. 2005. Official Method of Analysis of the Association of Official Analytical
Chemist. Virginia (US): Published by The Association of Analytical Chemist, inc.

[AOCS] American Oil Chemists Society. 1998. Free Fatty Acids in: Official Methods and Recommended Practices of the American Oil Chemists Society. Vol. 5a. $5^{\text {th }}$ ed. Champaign (US): AOCS Press.

Bligh EG, Dyer WJ. 1959. A rapid method of total lipid extraction and purification. Canadian Journal of Biochemistry and Physiology. 37(8):911-917.

[BSN] Badan Standardisasi Nasional. 2011. SNI 2354.5: 2011. Cara Uji KimiaBagian 5: Penentuan Kadar Logam Berat Timbal (Pb) dan Kadmium (Cd) Pada Produk Perikanan. Jakarta (ID): Badan Standarisasi Nasional.

[BSN] Badan Standardisasi Nasional. 2013. SNI 2729:2013: Ikan Segar. Jakarta (ID): Badan Standarisasi Nasional.

[BSN] Badan Standardisasi Nasional. 2015. SNI 2346:2015. Pedoman Pengujian Sensori pada Produk Perikanan. Jakarta (ID): Badan Standarisasi Nasional.

[BSN] Badan Standardisasi Nasional. 2016. SNI 2354.6:2016. Cara Uji Kimia - Bagian 6: Penentuan Kadar Logam Berat Merkuri (Hg) Pada Produk Perikanan. Jakarta (ID): Badan Standarisasi Nasional.

[BSN] Badan Standardisasi Nasional. 2017. SNI 2354.15:2017. Cara Uji Kimia Bagian 15: Penentuan Arsen (As) Total Pada Produk Perikanan. Jakarta (ID): Badan Standarisasi Nasional.

[CAC] Codex Alimentarius Commission. 1995. Standard for Contaminants and Toxins in Food and Feed CODEX STAN 193-1995. Roma (IT): Food and Agriculture Organization of the United Nations.

[CAC] Codex Alimentarius Commission. 2017. Standard for Fish Oils CSX 3292017. Roma (IT): Food and Agriculture Organization of the United Nations.

Carvajal AK, Mozuraityte R. 2016. Fish oils: production and properties. Encyclopedia of Food and Health. 693-698.

Damodaran S, Parkin KL. 2017. Fennema's Food Chemistry Fifth Edition. Florida (US): CRC Press of Taylor and Francis Group. 
Folch J, Lees M, Sloane-Stanley GH. 1957. A simple method for the isolation and purification of total lipides from animal tissues. Journal of Biological Chemistry. 226(1):497-509.

Iberahim NI, Hamzah Z, Yin YJ, Sohaimi KSA. 2018. Extraction and characterization of omega-3 fatty acid from catfish using enzymatic hydrolysis technique. MATEC Web of Conferences. 187:1-7.

Iberahim NI, Izzati N, Hann YC, Hamzah Z, Sohaimi KSA. 2020. Extraction of omega-3 fatty acid from jade perch (Scortum barcoo) using enzymatic hydrolysis technique. Indonesian Journal of Chemistry. 20(2):282-291.

Kaushik P, Dowling K, Barrow CJ, Adhikari B. 2015. Microencapsulation of omega-3 fatty acids: a review of microencapsulation and characterization methods. Journal of Functional Foods. 19:868-881.

[KKP] Kementerian Kelautan dan Perikanan. 2017. Laporan Kinerja Kementrian Kelautan dan Perikanan. Jakarta (ID): Kementrian Kelautan dan Perikanan.

Liu Y, Ramakrishnan VV, Dave D. 2020. Enzymatic hydrolysis of farmed Atlantic salmon by-products: investigation of operational parameters on extracted oil yield and quality. Journal of Process Biochemistry. 100:10-19.

Liu Y, Ramakrishnan VV, Dave D. 2020. Lipid class and fatty acid composition of oil extracted from atlantic salmon by-product under different optimization parameters of enzymatic hydrolysis. Biocatalysis and Agricultural Biotechnology. 30:1-14.

Mahesar SA, Sherazi STH, Khaskheli AR, Kandhro AA, Uddin S. 2014. Analytical approaches for the assessment of free fatty acids in oils and fats. Journal of Analytical Methods. 6(14):4956-4963.

Mbatia B, Adlercreutz D, Adlercreutz P, Mahadhy A, Mulaa F, Mattiasson B. 2010. Enzymatic oil extraction and positional analysis of $\omega-3$ fatty acids in Nile perch and salmon heads. Journal of Process Biochemistry. 45(5):815-819.

Mohanty BP, et al. 2016. DHA and EPA content and fatty acid profile of 39 food fishes from india. Biomed Research
International. 1-14.

Murado MA, Montemayor MI, Cabo ML, Vázquez JA, González MP. 2012. Optimization of extraction and purification process of hyaluronic acid from fish eyeball. Journal of Food and Bioproducts Processing. 90(3):491-498.

Qi-Yuan L, Jun-Qing Q, Xiao-Ge W. 2016. Optimization of enzymatic fish oil extraction from mackerel viscera by response surface methodology. International Food Research Journal. 23(3):992-997.

Ramakrishnan VV, Ghaly AE, Brooks MS, Budge SM. 2013. Extraction of Oil from mackerel fish processing waste using alcalase enzyme. Journal of Enzyme Engineering. 02(2):1-13.

Renuka V, Anandan R, Suseela M, Ravishankar CN, Sivaraman GK. 2016. Fatty acid profile of yellowfin tuna eye (Thunnus albacares) and oil sardine muscle (Sardinella longiceps). Journal of Fishery Technology. 53(2):151-154.

Riyanto B. 2013. Potensi Besar Hasil Samping Tuna. Seafood Update Magazine. ed 1: 2226.

Rubio-Rodríguez N, De Diego SM, Beltrán S, Jaime I, Sanz MT, Rovira J. 2012. Supercritical fluid extraction of fish oil from fish by-products: a comparison with other extraction methods. Journal of Food Engineering. 109(2):238-248.

Rustad T. 2010. Lipid Oxidation. Ed. Nollet LML, Toldra F. Handbook of Seafood and Seafood Products Analysis. Florida (US): CRC Press of Taylor and Francis Group.

Sullivan JC, Budge SM. 2010. Monitoring fish oil volatiles to assess the quality of fish oil. Journal of Lipid Technology. 22(10):230232.

Trilaksani W, Santoso J, Riyanto B, Ramadhan W, Rieuwpassa FJ. 2014. Fatty acid and amino acid profile of fat and fish roe protein concentrate recovered from skipjack (Katsuwonus pelamis) roes. MBRIO Conference. Bogor Agricultural University.

Trilaksani W, Riyanto B, Azzahra F, Santoso J, Tarman K. 2020. Recovery of tuna virgin fish oil and formulation as a product 
model of emulsion food supplement. IOP Conference Series: Earth and Environmental Science. 414(1):1-4.

Trilaksani W, Riyanto B, Syifa AL. 2020. Extraction and microencapsulation of tuna virgin fish oil with mangrove fruit extract fortified into extrusion cereals. IOP Conference Series: Earth and Environmental Science. 420(1):1-4.
Van-Leeuwen EM, Emri E, Merle BMJ, Colijn JM, Kersten E, Cougnard-Gregoire A, Dammeier S, Meester-Smoor M, Pool FM, de-Jong EK, Delcourt C, RodrigezBocanegra $\mathrm{E}$, Biarnés $\mathrm{M}$, Luthert $\mathrm{PJ}$, Ueffing M, Klaver CCW, Nogoceke E, den-Hollander AI, Lengyel I. 2018. A new perspective on lipid research in agerelated macular degeneration. Progress in Retinal and Eye Research. 67(1):56-86. 